\title{
Ekstrak Etanol Kulit Buah Jengkol Menurunkan Kadar Glukosa dan Meningkatkan Hormon Insulin Tikus Diabetes Yang Diinduksi Streptozotocin
}

\author{
(ETHANOL EXTRACT OF ARCHIDENDRON PAUCIFLORUM FRUIT PSEL \\ REDUCES GLUCOSE LEVELS AND IMPROVES INSULIN HORMONES \\ OF DIABETES RATS DUE TO STREPTOZOTOCIN INDUCTION)
}

\author{
Desak Made Malinie ${ }^{e}$, Madihah, Dita Aprila Khoirunnisa, \\ Indriani Sasmita, Nining Ratningsih, Kartiawati Alipin, Wawan Hermawan
}

Program Studi Biologi,

Fakultas Matematika dan Ilmu Pengetahuan Alam,

Universitas Padjadjaran

Jl. Raya Bandung Sumedang Km.21, Jatinangor, Sumedang, Jawa Barat, Indonesia 45363

Tlp. (022-7796412); e\&Email: desak.made@unpad.ac.id

\begin{abstract}
ABSTRAK
Diabetes mellitus (DM) merupakan penyakit gangguan metabolisme yang ditandai dengan meningkatnya kadar glukosa darah (hiperglikemia) akibat gangguan sekresi insulin dan atau meningkatnya resistensi insulin. Terapi kulit buah jengkol (Archidendron pauciflorum) merupakan salah satu pengobatan alternatif penyakit DM. Penelitian ini dilakukan untuk membuktikan pengaruh pemberian ekstrak etanol kulit buah jengkol (EEKBJ) terhadap kadar glukosa dan hormon insulin pada tikus diabetes yang diinduksi streptozotocin. Penelitian ini menggunakan metode eksperimental dengan Rancangan Acak Lengkap (RAL). Tikus terlebih dahulu diinduksi dengan injeksi tunggal STZ dosis $65 \mathrm{mg} / \mathrm{kg}$ BB secara intravena kecuali Kontrol Negatif. Tikus dibagi dalam enam kelompok, yaitu Kontrol Negatif (KN), Kontrol Positif (KP), Pembanding ( $\mathrm{Pb}$ ) glibenklamid $10 \mathrm{mg} / \mathrm{kg} \mathrm{BB}$, dan perlakuan ekstrak etanol kulit buah jengkol masing-masing dengan dosis 385 (P1), 770 (P2), dan $1540(\mathrm{P} 3) \mathrm{mg} / \mathrm{kg}$ BB dengan pengulangan sebanyak empat kali. Perlakuan diberikan secara oral setiap hari selama 14 hari. Data yang diperoleh dianalisis dengan analisis varians (ANAVA) dengan taraf kepercayaan 95\% dan dilanjutkan dengan uji Jarak berganda Duncan. Hasil penelitian menunjukkan bahwa pemberian terapi ekstrak etanol kulit buah jengkol dosis 385; 770 dan $1.540 \mathrm{mg} / \mathrm{kgBB}$ pada tikus induksi STZ menunjukkan penurunan kadar glukosa darah berturut-turut sebesar $28,6 \% ; 65,4 \%$ dan $59,1 \%$ dan peningkatan kadar insulin sebesar $54 \%$; $230 \%$ dan $206 \%$. Berdasarkan penelitian ini dapat disimpulkan bahwa dosis $770 \mathrm{mg} / \mathrm{kgBB}$ adalah dosis yang paling efektif dalam penurunan kadar glukosa dan peningkatan hormon insulin pada tikus diabetes yang diinduksi STZ.
\end{abstract}

Kata-kata kunci: ekstrak etanol kulit buah jengkol: insulin; STZ; glukosa

\begin{abstract}
Diabetes Mellitus (DM) is a disease with metabolism disorder signed by increasing of glucose blood (hyperglicemia), caused by disorder of insulin secretion and or increasing of insulin resistance. Therapy of jengkol's fruit peel is an alternative treatment for DM. This study aims to determine the effect of ethanol extract of jengkol's fruit peel to decrease glucose and increase insulin level of Wistar female rats which induced by streptozotocin (STZ). This research used the experimental method of Completely Randomized Design (RAL). Rat were first induced by single intravenous injection of STZ except Negative Control. Furthermore, rats were divided into six groups, namely Negative Control (NC), Positive Control (PC), Reference Group (RG) glibenclamide $10 \mathrm{mg} / \mathrm{kg} \mathrm{BW}$, and ethanol extract of jengkol's fruit peel (EEOJFP) treatment at dose of 385 (P1), 770 (P2), and 1540 (P3) $\mathrm{mg} / \mathrm{kg}$ BW with four replications each. Treatment was administered orally
\end{abstract}


for 14 days. Data were analyzed by analysis of variance (ANAVA) with 95\% confidence level and Duncan Multiple Range Test. The result showed that treatment of EEOJFP with dose of 385, 770 and $1540 \mathrm{mg} /$ kgBW decreased blood glucose $28.6 \% ; 65.4 \%$ and $59.1 \%$ successively, increased insulin as 54\%; $230 \%$ and $206 \%$. There was a protective effect of EEOJEF to level of blood glucose and insulin secretion of rat-STZ induced. The conclusion from this research is Ethanol extract of Jengkol's fruit peel at dose $770 \mathrm{mg} / \mathrm{kg} \mathrm{BW}$ is an effective dose in decreasing the level of glucose and increasing the level of insulin hormone in STZinduced diabetic rats

Keywords: ethanol extract of jengkol's fruit peel ; STZ; insuline ,glucose

\section{PENDAHULUAN}

Diabetes mellitus (DM) adalah salah satu penyakit gangguan metabolisme yang ditandai dengan kadar gula darah tinggi (hiperglikemia) akibat penurunan sekresi dan resistensi insulin atau keduanya, dan kegagalan insulin mempengaruhi jaringan dan organ target (Dey et al., 2015; Ahmad et al., 2014). Hiperglikemia yang berlangsung lama (kronik) dan tidak diobati akan menyebabkan kerusakan gangguan fungsi, kegagalan berbagai organ, terutama mata, ginjal, hati, saraf, jantung dan pembuluh darah lainnya (Vasconcelos et al., 2011).

Insulin merupakan hormon peptida yang disekresikan oleh sel $\alpha$ dari langerhans pancreas yang berfungsi untuk mengatur kadar glukosa dalam darah. Hormon insulin bekerja dengan cara memperantarai uptake glukosa seluler, regulasi metabolisme karbohidrat, lemak, dan protein, serta mendorong pemisahan dan pertumbuhan sel melalui efek motigenik (Wilcox 2005). Defisiensi insulin menyebabkan glukosa tidak dapat masuk ke dalam sel, sehingga kadar glukosa di dalam darah akan meningkat atau hiperglikemia dan akibatnya glukosa yang masuk ke dalam tubuh tidak bisa dimanfaatkan untuk menghasilkan energi

Menurut International Diabetes Federation (IDF) tahun 2012, kejadian diabetes di dunia semakin lama semakin meningkat yaitu pada tahun 2012 jumlah penderita DM 371 juta kasus, meningkat menjadi 382 juta kasus pada tahun 2013 dan pada tahun 2014 mengalami peningkatan menjadi menjadi 387 juta kasus. Prediksi IDF pada tahun 2035 jumlah insiden DM akan mengalami peningkatan menjadi 592 juta di seluruh dunia dan $80 \%$ penderitanya merupakan penduduk negara yang berpenghasilan rendah dan menengah. Negara Indonesia menduduki peringkat ke tujuh kejadian diabetes tertinggi, setelah Cina, India, Amerika, Brazil, Rusia, dan Mexico. Jumlah penderita DM di Indonesia adalah 8,5 juta kasus.
Jumlah ini diperkirakan akan bertambah pada tahun 2035 menjadi 14,1 juta kasus (IDF, 2015).

Penanganan penyakit Diabetes melitus memerlukan perhatian yang serius karena pemakaian obat-obatan sintesis dapat menimbulkan efek samping yang merugikan kesehatan diantaranya adalah penambahan berat badan, edema, hipoglikemia, asidosis laktat, toksisitas pada hati, gangguan sistem pencernaan dan resistensi insulin setelah pemakaian jangka panjang (Zhang et. al., 2016). Adanya dampak buruk yang ditimbulkan akibat obat-obatan sintesis yang digunakan dalam menangani DM menjadi alasan utama dilakukan pencarian obat anti hiperglikemia alami. Pada saat ini obat tradisional yang berasal dari tumbuhan banyak digunakan oleh masyarakat untuk pengobatan alternatif (Dewoto, 2007). Hal ini disebabkan karena tumbuhan memiliki kandungan kimia yang beragam, memiliki aktivitas yang luas dan tidak memiliki efek samping seperti halnya obatobat kimiawi.

Salah satu tumbuhan yang digunakan sebagai obat herbal adalah kulit buah jengkol. Masyarakat Desa Karangwangi, Cianjur Jawa Barat, menggunakan kulit buah jengkol sebagai obat untuk penyakit diabetes, karena tidak memiliki efek samping, mudah didapat dan mudah mengolahnya sebagai obat (Malini et al., 2016). Menurut Sihombing et al., (2015), kandungan senyawa kimia yang terdapat pada kulit buah jengkol adalah alkaloid, flavonoid, tanin, saponin, dan polifenol. Beberapa senyawa flavonoid seperti genistein dapat meningkatkan sekresi insulin pada sel â pancreas (Ohno et al., 1993). Quercetin dari golongan senyawa flavonoid juga dapat menurunkan kadar glukosa pada tikus diabetes, mengurangi kolesterol plasma dan trigliserida, dan meningkatkan aktivitas glukokinase hati tikus dengan cara meningkatkan pelepasan insulin dari pankreas tikus model diabetes (Vessal et al., 2003). 
Senyawa alkaloid seperti harmane dan norharmine dapat merangsang sekresi insulin. Harmane, norharmane dan pinoline dapat meningkatkan sekresi insulin 2-3 kali lipat dari pulau-pulau Langerhans (Nandkarni, 1992). Oleh karena itu, pada penelitian ini akan diuji potensi ekstrak etanol kulit buah jengkol dalam menurunkan kadar glukosa darah dan meningkatkan kadar hormon insulin pada tikus model diabet yang diinduksi STZ.

\section{METODE PENELITIAN}

\section{Metode Penelitian}

Penelitian ini dilakukan secara eksperimental di laboratorium, menggunakan Rancangan Acak Lengkap (RAL) faktor tunggal dengan enam perlakuan dan empat ulangan. Model hewan diabetes yang digunakan adalah tikus wistar betina ( $R$. norvegicus) yang memiliki kadar glukosa e" $250 \mathrm{mg} / \mathrm{dl}$ pada hari ke-4 setelah induksi dengan STZ (Sajedianfard, 2014). Semua kelompok perlakuan diinduksi diabetes kecuali kontrol negatif (KN). Perlakuan yang diberikan yaitu kontrol negatif (KN) diberi CMC 0,5\%, kontrol positif (KP) diberi CMC 0,5\%, pembanding (PB) diberi Glibenklamid $10 \mathrm{mg} / \mathrm{kg}$ BB, Perlakuan 1, 2 dan 3 diberi ekstrak etanol kulit buah jengkol masingmasing dosis 385 (P1), 770 (P2), dan 1540 (P3) $\mathrm{mg} / \mathrm{kg}$ BB. Perlakuan diberikan satu kali sehari selama 14 hari berturut-turut dengan cara oral.

\section{Prosedur kerja}

Ekstrak etanol kulit buah jengkol dilakukan dengan metode maserasi menggunakan pelarut etanol 70\%. Kulit buah jengkol dipotong kecilkecil, dicuci, dikering-anginkan dan kemudian diblender hingga berbentuk serbuk simplisia. Serbuk simplisia dimaserasi dengan menggunakan etanol $70 \%$ dan serbuk $2: 1$. Perendaman dilakukan selama 3 x 24 jam. Maserat yang diperoleh, disaring dan diuapkan dengan menggunakan rotary evaporator pada suhu $40^{\circ} \mathrm{C}$ sampai diperoleh ekstrak dalam bentuk pasta (Khan et al. 2010). Induksi diabetes hewan uji dilakukan dengan cara injeksi tunggal streptozotocin (STZ) secara intravena dengan dosis $65 \mathrm{mg} / \mathrm{kg}$ BB yang dilarutkan dengan larutan 0,1 M citrate buffer $(\mathrm{pH} 4,5)$. Sebelum diinduksi tikus dipuasakan terlebih dahulu selama 12 jam dan diukur kadar glukosa darahnya. Tikus dianggap menderita diabetes dan dapat digunakan sebagai hewan uji apabila kadar glukosa darahnya $>250 \mathrm{mg} / \mathrm{dl}$ setelah 72 jam induksi (Sajedianfard et al., 2014).

\section{Pemeliharaan Hewan Uji}

Hewan uji dipelihara dalam kandang hewan di Laboratorium Biosistem FMIPA Unpad dengan temperatur antara $23-25^{\circ} \mathrm{C}$, pencahayaan 12 jam gelap dan 12 jam terang. Penggantian sekam alas kandang dilakukan secara berkala $2 x$ seminggu. Selama perlakuan hewan uji diberi pakan komersial (CP-551® PT. Charoen Pokhpand, Indonesia) dan minum berupa air kran secara ad libitum.

\section{Pengukuran kadar glukosa darah dan in- sulin}

Pengukuran kadar glukosa darah dilakukan setelah tikus dipuasakan selama 12 jam menggunakan alat glucometer. Pengambilan sampel darah untuk pengukuran kadar glukosa darah dilakukan dengan melukai vena ekor mencit, kemudian darah yang keluar dari ekor mencit diteteskan pada stripe yang sudah terpasang pada glucometer. Pengu-kuran kadar glukosa darah dilakukan pada hari ke-0, 7 dan 16.

Pengukuran kadar insulin plasma dilakukan setelah akhir masa perlakuan dengan menggunakan RAT INS (Insulin) ELISA Kit FineTest ER1113 dan alat microplate reader. Sampel darah untuk pengukuran kadar insulin plasma diambil dari dari jantung hewan uji. Sampel darah yang diperoleh disentrifugasi dengan kecepatan $3000 \mathrm{rpm}$ pada suhu $4^{\circ} \mathrm{C}$ selama 30 menit. Serum darah diambil dari supernatant dan selanjutnya direaksikan dengan monoclonal anti-mouse insulin (antibodi) yang telah dilapisi pada dasar sumur-sumur microplate dan reagents yang tersedia dalam rat insulin ELISA kit. Setelah melalui beberapa reaksi tersebut, sampel tersebut diukur dengan alat microplate reader pada panjang gelombang $450 \mathrm{~nm}$.

\section{Analisis Data}

Data yang diperoleh selanjutnya dianalisis dengan analisis varians (ANAVA) dengan taraf kepercayaan 95\% (á=5\%) dan uji Jarak berganda Duncan 


\section{HASIL DAN PEMBAHASAN}

\section{Hasil}

Hasil pengukuran kadar glukosa darah (KGD) pada kelompok tikus kontrol, DM dan perlakuan ekstrak etanol kulit buah jengkol dilakukan pada hari ke-0, 7 dan 14 pascainduksi STZ dan pemberian perlakuan ekstrak etanol kulit buah jengkol dengan dosis 385, 770 dan 1.540 $\mathrm{mg} / \mathrm{kg}$ BB ditampilkan pada Tabel 1. Pada Tabel 1 tampak bahwa terjadi peningkatan KGD setelah induksi STZ dan penurunan KGD setelah mendapatkan perlakuan ekstrak kulit buah jengkol dan glibenklamid. Pada hari ke-7, rataan KGD KN berbeda nyata dengan KGD perlakuan lainnya baik yang diberi perlakuan Ekstrak Etanol kulit buah jengkol maupun yang diberi Glibenklamid sedangkan antar perlakuan tersebut tidak menunjukkan adanya perbedaan yang nyata. Pada hari ke 14, rataan KGD tikus KN termasuk dalam rentang KGD tikus normal yaitu $50-135 \mathrm{mg} / \mathrm{dl}$ (De et al., 2010), sedangkan kelompok tikus yang diinduksi intravena STZ dosis $65 \mathrm{mg} / \mathrm{kgBB}$ (KP) sebesar $321,3 \mathrm{mg} / \mathrm{dL}$ termasuk dalam rentang
KGD tikus DM yaitu lebih besar dari e" $250 \mathrm{mg} /$ dL. KGD kelompok perlakuan ekstrak etanol kulit buah jengkol P1 tidak berbeda nyata dengan KGD KP, sedangkan KGD kelompok P2 dan P3 mendekati normal dan secara statistik tidak berbeda nyata dengan KGD KN dan PB namun menunjukkan perbedaan yang nyata apabila dibandingkan dengan KGD KP. Semua perlakuan ekstrak etanol kulit buah jengkol yang diberikan dapat menurunkan KGD masing-masing sebanyak $28,7 \%, 65,4 \%$ dan $59,1 \%$ untuk P1, P2 dan P3, dan Kelompok PB (Glibenklamid) dapat menurunkan KGD sebanyak $59,7 \%$

Rataan kadar insulin plasma pada kelompok tikus kontrol, DM dan tikus yang diberi perlakuan ekstrak etanol kulit buah jengkol dosis 385, 770 dan $1.540 \mathrm{mg} / \mathrm{kg} \mathrm{BB}$ disajikan pada Tabel 2. Pada Tabel 2 tampak bahwa pemberian ekstrak etanol kulit buah jengkol dapat meningkatkan kadar insulin plasma. Kadar hormon insulin pada tikus diabetes (KP) lebih rendah secara signifikan jika dibandingkan dengan kelompok tikus KN dan kelompok perlakuan lainnya, sedangkan kelompok tikus perlakuan

Tabel 1. Rataan kadar glukosa darah tikus (Rattus norvegicus) yang diberi perlakuan

\begin{tabular}{|c|c|c|c|c|}
\hline \multirow{2}{*}{ Perlakuan } & \multicolumn{3}{|c|}{ Kadar Glukosa Darah (KGD) (mg/dL) } & \multirow[b]{2}{*}{$\begin{array}{c}\text { Persentase } \\
\text { Penurunan } \\
\text { Kadar Glukosa } \\
\text { Darah Puasa (\%) }\end{array}$} \\
\hline & Hari ke-0 & Hari ke-7 & Hari ke-14 & \\
\hline $\begin{array}{l}\text { Kontrol Negatif }(\mathrm{KN}) \text { : } \\
\text { CMC } 0,5 \%\end{array}$ & $122,8 \pm 3,72^{\mathrm{a}}$ & $123,3 \pm 9,36^{\mathrm{a}}$ & $125,5 \pm 5,80^{\mathrm{a}}$ & $-2,1$ \\
\hline $\begin{array}{l}\text { Kontrol Positif (KP): } \\
\text { STZ +CMC 0,5\% }\end{array}$ & $359,3 \pm 4,21^{\mathrm{b}}$ & $337,3 \pm 6,56^{\mathrm{b}}$ & $321,3 \pm 7,39^{b}$ & 7,7 \\
\hline $\begin{array}{l}\text { Perlakuan } 1 \text { (P1): STZ + } \\
\text { Ekstrak etanol kulit buah } \\
\text { jengkol } 385 \mathrm{mg} / \mathrm{kg} \mathrm{BB}\end{array}$ & $487,0 \pm 6,16^{\mathrm{c}}$ & $408,5 \pm 6,31^{\mathrm{c}}$ & $347,5 \pm 7,33^{b}$ & 28,6 \\
\hline $\begin{array}{l}\text { Perlakuan } 2 \text { (P2): STZ + } \\
\text { Ekstrak etanol kulit buah } \\
\text { jengkol } 770 \mathrm{mg} / \mathrm{kg} \mathrm{BB}\end{array}$ & $364,5 \pm 9,14^{\mathrm{b}}$ & $333,0 \pm 3,34^{\mathrm{b}}$ & $126,0 \pm 2,83^{\mathrm{a}}$ & 65,4 \\
\hline $\begin{array}{l}\text { Perlakuan } 3 \text { (P3): STZ + } \\
\text { Ekstrak etanol kulit buah } \\
\text { jengkol } 1540 \mathrm{mg} / \mathrm{kg} \mathrm{BB}\end{array}$ & $444,3 \pm 1,37^{\mathrm{c}}$ & $326,5 \pm 8,61^{b}$ & $181,5 \pm 3,60^{a}$ & 59,1 \\
\hline $\begin{array}{l}\text { Pembanding (PB): STZ + } \\
\text { Glibenklamid } 10 \mathrm{mg} / \mathrm{kg} \text { BB }\end{array}$ & $483,0 \pm 9,70^{c}$ & $384,5 \pm 6,63^{\mathrm{b}}$ & $194,5 \pm 4,20^{\mathrm{a}}$ & 59,7 \\
\hline
\end{tabular}

Keterangan:Data disajikan dalam bentuk $x^{\sim} \pm$ SD. Analisis data menggunakan ANAVA dengan taraf kepercayaan 95\% dan uji lanjut Duncan. Huruf yang berbeda pada satu kolom menunjukkan perbedaan signifikan $(\mathrm{p}<0,05)$ 
glibenklamid (PB) lebih rendah secara signifikan jika dibandingkan dengan tikus P2 dan P3, namun tidak berbeda nyata dengan kelompok tikus P1. Berdasarkan hasil tersebut maka dapat disimpulkan bahwa pemberian ekstrak etanol kulit buah jengkol dengan dosis $770 \mathrm{mg} /$ $\mathrm{kg}$ BB dapat menyebabkan kadar insulin mendekati kisaran normal. Hal ini sesuai dengan data kadar glukosa darah yang menunjukkan bahwa pemberian dosis $770 \mathrm{mg} /$ $\mathrm{kg}$ BB dapat memberikan pengaruh penurunan kadar glukosa darah yang tidak berbeda nyata dengan kontrol negatif.

\section{Pembahasan}

Pada penelitian ini kelompok tikus KP (diinduksi STZ) menunjukkan ciri khas dari penderita penyakit Diabetes Melitus (DM) yaitu memiliki kadar glukosa darah yang tinggi dan kadar hormon insulin yang rendah. Penyakit DM dapat terjadi akibat dari adanya kerusakan sel â pankreas. Organ pankreas yang rusak tidak dapat menghasilkan hormon insulin atau tidak dapat menggunakan insulin yang dihasilkan secara efektif (Gaikwad et al., 2014). Insulin merupakan hormon yang diproduksi organ pankreas untuk mengendalikan kadar glukosa dalam darah dan kekurangan insulin dapat menyebabkan terjadinya peningkatan kadar glukosa dalam darah (World Health Organization, 1999).

Streptozotocin (STZ) yang diberikan pada tikus melalui intravena dapat merusak sel $\alpha$ pankreas karena STZ bersifat sitotoksik spesifik pada sel $\alpha$ pankreas dan akibatnya fungsi sel $\alpha$ sebagai penghasil hormon insulin akan terganggu dan menginduksi terjadinya DM (Pathak et al., 2008). Menurut Wilson et al.
(1998), STZ dapat merusak DNA sel $\alpha$ pulau pankreas. Kerusakan DNA terjadi karena adanya alkilasi yang dimediasi STZ, sehingga diperlukan sintesis NAD-Dependent Enzyme Poly (ADP-ribose) (PARP) (Wilson and Leiter, 1990; Lenzen, 2008). Hal ini menyebabkan overstimulus dalam mekanisme perbaikan DNA pada enzim sel $\alpha$ yang terus diaktifkan, sehingga kadar Nicotinamide Adenine Dinucleotide $\left(\mathrm{NAD}^{+}\right)$dan ATP semakin berkurang. Kadar $\mathrm{NAD}^{+}$dan ATP yang semakin berkurang menghambat sintesis insulin dan menginduksi terjadinya kondisi diabetes yang ditandai dengan meningkatnya kadar glukosa (hiperglikemia). Kadar $\mathrm{NAD}^{+}$yang terus menurun dapat menghentikan fungsi seluler dan akhirnya menyebabkan kematian sel $\alpha$ (Wilson and Leiter, 1990).

Kelompok tikus yang diberi Gliben-klamid menunjukkan adanya penurunan yang signifikan KGD dan peningkatan kadar hormon insulin apabila dibandingkan dengan KP. Hal ini dapat terjadi karena adanya kemampuan Glibenklamid untuk merangsang sel â pankreas mensekresi hormon insulin (Soegondo, 2005). Saluran kalium yang peka Adenosin trifosfat $\left(\mathrm{K}^{+} \mathrm{ATP}\right)$ pada sel â pankreas berperan penting dalam pelepasan insulin. Apabila glibenklamid terikat pada reseptor transmembran sulfonilurea (SUR-1) maka akan terjadi penutupan saluran $\mathrm{K}^{+} \mathrm{ATP}$. Efluks seluler dari Kalium berkurang dan terjadi depolarisasi membran. Sedangkan kalsium mengalami influks yang dimediasi oleh pembukaan saluran $\mathrm{Ca}^{2+}$ dan mensti-mulasi pelepasan insulin (Bösenberg dan Van Zyl, 2008). Adanya insulin ini akan meningkatkan pengambilan glukosa oleh sel (Murrray et.al., 2009) dan akibatnya

Tabel 2. Rataan kadar hormon insulin tikus wistar betina dari tiap perlakuan

Perlakuan

Kadar Hormon Insulin $(\mathrm{mIU} / \mathrm{L})$

Kontrol Negatif (KN) : CMC 0,5\%

Kontrol Positif (KP): STZ +CMC 0,5\%

Perlakuan 1 (P1): STZ + Ekstrak etanol kulit buah jengkol $385 \mathrm{mg} / \mathrm{kg}$ BB

$2,65 \pm 1,18^{\mathrm{c}}$

$0,72 \pm 0,54^{\mathrm{a}}$

$1,11 \pm 0,49^{\mathrm{b}}$

Perlakuan 2 (P2): STZ + Ekstrak etanol kulit buah jengkol $770 \mathrm{mg} / \mathrm{kg}$ BB $2,48 \pm 0,19^{\mathrm{c}}$

Perlakuan 3 (P3): STZ + Ekstrak etanol kulit buah jengkol $1540 \mathrm{mg} / \mathrm{kg}$ BB 2,21 $\pm 1,52^{\text {c }}$

Pembanding $(\mathrm{Pb})$ : STZ + Glibenklamid $10 \mathrm{mg} / \mathrm{kg}$ BB

$1,21 \pm 0,58^{\mathrm{b}}$

Keterangan : Data disajikan dalam bentuk $x^{\sim} \pm$ SD. Analisis data menggunakan ANAVA dengan taraf kepercayaan 95\% dan uji lanjut Duncan. Huruf yang berbeda pada satu kolom menunjukkan perbedaan signifikan $(\mathrm{p}<0,05)$. 
terjadi penurunan kadar glukosa di dalam darah.

Penurunan KGD dan peningkatan kadar hormon insulin pada kelompok tikus yang diberi ekstrak etanol kulit buah jengkol diduga karena adanya senyawa kimia bioaktif yang terkandung di dalam kulit buah jengkol yang mampu merangsang sel beta pankreas untuk mensekresi hormon insulin. Ekstrak kulit buah jengkol mengandung beberapa senyawa bioaktif diantaranya adalah flavonoid, alkaloid, tanin dan polifenol (Muslim et al., 2012; Syafnir dan Krishnamurti, 2015). Tumbuhan yang memiliki senyawa metabolik sekunder flavonoid dapat digunakan untuk menyembuhkan diabetes dengan cara merangsang sekresi hormon insulin (Waltner-Law, 2002), contohnya genistein, daidzein, quercetin, rutin, catechin, epicatechins dan epigallocatechin-gallate (EGCG) secara in vitro dan in vivo (Pinent et al., 2008). Flavonoid merupakan senyawa metabolit sekunder yang paling banyak ditemukan di jaringan tumbuhan dan diduga mampu meregenerasi sel â pankreas yang rusak (Du Thie dan Crozier, 2000; Birben et al., 2012). Tumbuhan jengkol (Archidendron pauciflo rum) termasuk familia fabacea dan menurut Unnikrishnan et al., (2013), tanaman yang termasuk ke dalam golongan fabaceae mengandung senyawa flavonoid jenis Isoflavones (3-phenylchromen-4-ones or 3-phenyl-a-benzopyrones) yang terdiri dari genistein, daidzein, glycitein, formononetin, biochanin-A, dan wighteone. Genistein dan daidzein terbukti dapat meningkatkan sekresi insulin pada sel â pankreas tikus (Persaud et al., 1999). Hal ini sejalan dengan penelitian Lee (2006), bahwa pemberian suplemen genistein pada tikus Sparague-Dawley jantan yang diinduksi STZ dapat meningkatkan kadar hormon insulin dan melindungi fungsi sel â dari pengaruh STZ. Menurut Lugasi et al., (2003), Flavonoid mampu menangkap radikal bebas atau berfungsi sebagai antioksidan alami. Aktivitas antioksidan tersebut memungkinkan flavonoid untuk menangkap atau menetralkan radikal bebas (seperti ROS atau RNS) terkait dengan gugus $\mathrm{OH}$ fenolik sehingga dapat memperbaiki keadaan jaringan yang rusak. Aksi flavonoid pada diabetes mellitus adalah menghindari absorbsi glukosa atau memperbaiki toleransi glukosa. Flavonoid menstimulasi pengambilan glukosa pada jaringan perifer, mengatur aktivitas dan ekspresi enzim yang terlibat dalam jalur metabolisme karbohidrat serta dapat bertindak menyerupai insulin (insulino-mimetic) dengan cara mempengaruhi mekanisme insulin signaling. Flavonoid dapat berperan dalam perbaikan kerusakan jaringan pankreas yang diakibatkan oleh alkilasi DNA oleh induksi STZ dan akibatnya dapat meningkatkan sekresi insulin dalam darah dan kadar glukosa darah dapat diturunkan (Sandhar, 2011). Sehingga diduga senyawa flavonoid yang terkandung di dalam kulit buah jengkol juga dapat menurunkan KGD dan meningkatkan kadar hormone insulin pada tikus yang diinduksi STZ.

Senyawa lain yang terkandung dalam kulit buah jengkol adalah alkaloid, yaitu senyawa organik yang bersifat basa dan terdapat dalam tumbuh-tumbuhan (Sumardjo, 2008). Aktivitas antioksidan yang dimiliki ekstrak etanol kulit buah juga tinggi yaitu $66.82 \%$ sehingga diduga mampu memperbaiki sel $\alpha$ pankreas yang rusak. Aktivitas antioksidan mampu menangkap radikal bebas yang menyebabkan perbaikan pada kerusakan sel $\alpha$ pankreas penyebab DM. Dengan adanya perbaikan pada jaringan pankreas, maka terjadi peningkatan jumlah insulin didalam tubuh sehingga glukosa darah akan masuk kedalam sel sehingga terjadi penurunan glukosa darah dalam tubuh. Sehingga diduga senyawa alkaloid yang terkandung di dalam kulit buah jengkol dapat menurunkan KGD tikus yang diinduksi STZ.

Estrak etanol kulit buah jengkol juga mengandung senyawa kimia tanin yang termasuk ke dalam golongan senyawa polifenol yang tersebar luas dalam tumbuhan terutama dalam tumbuhan berpembuluh (Harborne, 1987). Tanin dapat menurunkan KGD dengan cara meningkatkan penyerapan glukosa (Kumari dan Jain, 2012). Tanin diketahui dapat memacu metabolisme glukosa dan lemak sehingga timbunan kedua sumber kalori ini dalam darah dapat dihindari. Tanin mempunyai aktivitas antioksidan dan menghambat pertumbuhan tumor. Tanin juga mempunyai aktivitas hipoglikemik yaitu dengan meningkatkan glikogenesis. Selain itu, tanin juga berfungsi sebagai astringent atau pengkhelat yang dapat mengerutkan membran epitel usus 
halus sehingga mengurangi penyerapan sari makanan dan sebagai akibatnya menghambat asupan gula dan laju peningkatan gula darah tidak terlalu tinggi. Hal yang sama ditunjukkan oleh hasil penelitian Zain dan Abu (2014), yaitu asam galat yang termasuk ke golongan senyawa kimia tanin yang terkandung dalam ekstrak etanol biji Pithecellobium jiringa dapat mereduksi KGD pada tikus yang diinduksi streptozotocin.

Dari hasil pengamatan fisiologi pada tikus diabet dapat disimpulkan bahwa senyawa kimia yang terdapat di dalam ekstrak etanol kulit buah jengkol mampu menurunkan kadar glukosa darah dan meningkatkan produksi hormon insulin.

\section{SIMPULAN}

Berdasarkan hasil yang diperoleh dalam penelitian ini, dapat disimpulkan bahwa ekstrak etanol kulit buah jengkol dapat menurunkan kadar glukosa darah dan insulin plasma.

\section{SARAN}

Dosis ekstrak etanol kulit buah jengkol $770 \mathrm{mg} / \mathrm{kg}$ BB merupakan dosis yang paling efektif dalam menurunkan kadar glukosa $(65,4 \%)$ dan meningkatkan kadar insulin plasma $(230 \%)$ tikus wistar diabetes yang diinduksi streptozotocin.

\section{UCAPAN TERIMA KASIH}

Pada kesempatan ini kami menghaturkan terima kasih kepada Kementerian Riset, Teknologi, dan Pendidikan Tinggi Republik Indonesia yang telah membiayai penelitian ini sesuai dengan no kontrak 718/UN6.3.1/PL/2017 tanggal 17 April 2017.

\section{DAFTAR PUSTAKA.}

American Diabetes Association (ADA). 2010. Standards of Medical Care in Diabetes. Diabetes Care 36 Supplement 1: 11-66.
De D, Chatterjee K, Ali KM, Bera TK, Ghosh Debidas. 2010. Antidiabetic Potentiality of the Aqueous- Methanolic Extract of Seed of Swieteniamahagoni (L.) Jacq. In Streptozotocin-Induced DiabeticMale Albino Rat: A Correlative and Evidence-Based Approach with Antioxidative and Antihyperlipidemic Activities. Evidence-Based Complementary and Alternative Medicine 2011: 11.

Dewoto HR. 2007. Pengembangan Obat Tradisional Indonesia menjadi Fitofarmaka. Majalah kedokteran Indonesia 57(7): 205-211.

Gaikwad SB, Mohan GK, Rani MS. 2014. Phytochemicals for Diabetes Management. Pharmaceutical Crops 5: 11-28.

IDF (International Diabetic Federation). Diabetes Research \& Clinical Practice: Global estimates of diabetes prevalence for 2013 \& projection for 2035. 2013. Diunduh 15 Desember 2015. www.idf.org

Khan ZI, Badrun N, Abu MJ, Shahnaz R, Majeedul HC, Rahmatullah M. 2010. An Evaluation of Antihyperglycemic and Antinociceptive Effects of Methanol Extract of Cassia Fistula L. (Fabaceae) Leaves in Swiss Albino Mice. Advances in Natural and Applied Sciences 4(3): 305310.

Lee JS. 2006. Effects of soy protein and genistein on blood glucose, antioxidant enzyme activities, and lipid profile in streptozotocin-induced diabetic rats. Life Sciences 79: 1578-1584.

Lugasi A, Hovari J, Sagi KV, Biro L. 2003. The Role of Antioxidant Phytonutrients In The Prevention of Disease. Acta Biologica Szegediensis 47: 119-125

Sandhar HK, Kumar B, Prashes S, Tiwari P, Salhan M, Sharma P. 2011. A Review Of Phytochemistry And Pharmacology Of Flavonoids. Internationale Pharmaceutica Scienca Jan-Mar 2011 Vol 1 Issue 1. http://www.ipharmsciencia.com

Malini DM, Madihah J, Kusmoro F, Kamilawati J, Iskandar. 2017. Ethnobotanical Study of Medicinal Plants in Karangwangi,District of Cianjur, West Java. Biosaintifika 9(2): 345-356. 
Nandkarni AK. 1992. Indian Materia Medica vol. 1. Bombay. Popular Prakashan.

Ohno T, Kato N, Ishii C, Shimizu M, Ito Y, Tomono S, Kawazu S. 1993 Genistein augments cyclic adenosine 3'5'monophosphate(cAMP) accumulation and insulin release in MIN6 cells. Endocrinology Research 19(4): 273-285.

Pathak M, Chatterjee TK., Chakraborty A, Sengupta GC. 2008. Effects of plant extract Centella asiatica (Linn.) on cold restraint stress ulcer in rats. Indian Journal Experimental Biology 30: 889891. PMID:1293014

Persaud S, Harris T, Burns C, Jones P. 1999 Tyrosine kinases play a permissive role in glucoseinduced insulin secretion from adult rat islets. Journal Moleculer Endocrinology 22(1): 19-28.

Pinent M, Castell A, Baiges I, Montagut G, Arola L, Ardvol A. 2008. Bioactivity of Flavonoids on Insulin-Secreting Cells. Comprehensive Reviwes in Food Science And Food Safety 7: 299-308.

Sajedianfard J, Behroozi Z, Nazifi S. 2014. The Effects Of A Hyroalcoholic Extract Of Silymarin On Serum Lipids Profiles In Streptozotocin Induced Diabetic Rats. Comparative Clinical Pathology 23(3): 779784 .

Sihombing JR, Dharma A, Chaidir, Z, Almahdy, Fachrial E, Munaf E. 2015 Phytochemical screening and antioxidant activities of 31 fruit peel extract from Sumatera, Indonesia. Journal of Chemistry and Pharmacology Research 7(11): 190-196.

Soegondo, S. (2004) Prinsip Pengobatan Diabetes, Insulin dan Obat Hipoglikemik Oral. Jakarta. Fakultas Kedokteran, Universitas Indonesia.

Syafnir L, Krishnamurti Y, Ilma M. 2014 Uji Aktivitas Antidiabetes Ekstrak Etanol Kulit Jengkol (Archidendron pauciflorum (Benth.) I.C. Nielsen). Prosiding SNaPP 2014 Sains, Teknologi, dan Kesehatan. ISSN 2089-3582 | EISSN 2303-2480
Unnikrishnan MK, Nayak Y, Veerapur V, Mather G.. 2013. Antidiabetic, Antihyperlipidemic and Antioxidant Effects of the Flavonoids. Polyphenols in Human Health and Disease 13: 143-161.

Vasconcelos CFB, Maranhão HML, Batista TM, Carneiro EM, Ferreira F, Costa J, Soares, LAL, Sá MDC, Souza TP, Wanderley AG. 2011. Hypoglycaemic activity and molecular mechanisms of CaesalpiniaferreaMartius bark extract on streptozotocin-induced diabetes in Wistar rats. Journal of Ethnopharmacology 137: 1533-1541.

Vessal M, Hemmati M, Vasei M. 2003. Hypoglycemic effects of quercetin in streptozocin-induced diabetic rats. Compharative Biochemistry Physiology Toxicol Pharmacology 135C: 357-364.

Waltner-Law ME, Wang XL, Law BK, Hall RK, Nawano M, Granner DK. 2002. Epigallocatechin gallate, a constituent of green tea, represses hepatic glucose production. J Biol Chem (277): 3493334940.

Wilcox, G. (2005) Insulin and Insulin Resistance. Clinic Biochemistry Review 26(2): 19-39.

Wilson GL, Patton NJ, McCord JM, Mullins DW, Mossman BT. 1998. Mechanisms of streptozotocin- and alloxan-induced damage in rat â cells. Diabetologia 27(6): 587-591.

Wilson GL, Leiter EH. 1990. Streptozotocin interactions with pancreatic â cells and the induction of insulindependent diabetes. Current Topics Microbiology Immuno 156: 27-54.

World Health Organization. Diabetes. (Online) 2006.http://www.who.int/ mediacentre/factsheets/fs312/en/

Zhang Y, Fu F, Ting C, Zhongwen L, Qingwu WS. 2016. Antidiabetic and antihiperlipidemic activities of Forsythia suspense (Thunb.) Vahl (Fruit) in Steptozotocininduced diabetes mice. Journal of Ethnopharma-cology 192: 256-263. 
